\title{
PERLINDUNGAN HUKUM TERHADAP ANAK YANG TEREKSPLOITASI SECARA EKONOMI DI KOTA PADANG
}

\author{
Laurensius Arliman S.
}

\author{
Sekolah Tinggi Ilmu Hukum (STIH) Padang \\ Jl. AR. Hakim No 6 Padang \\ Email: laurensiusarliman@gmail.com
}

\begin{abstract}
This paper examines and analyzes the role and constraints of the Department of Social Welfare and Labor of Padang in carrying out child protection economically exploited. This paper uses socio legal research. The results of this paper are: Department of Social Welfare and Labor of Padang has been quite active in implementing the protection of children who are economically exploited, by conducting raids, coaching and training. The obstacles foundwere classic, namely: the nature of the child, the family, the fade of religious values, education, community, economic, cultural shift, the lack of facilities for the development of children, the lack of human resources, and inadequate funds. The author expects that in the future the child is considered by the government of Padang and also by the Child Family and Community.
\end{abstract}

Key words: child, Department of Social Welfare and Labor, economics, padang, exploitation

\begin{abstract}
Abstrak
Tulisan ini meneliti serta menganalisis peran dan kendala-kendala Dinas Sosial dan Tenaga Kerja Kota Padang dalam menjalankan perlindungan anak yang dieksploitasi secara ekonomi. Tulisan ini menggunakan penelitian socio legal. Hasil dari tulisan ini adalah: Dinas Sosial dan Tenaga Kerja Kota Padang sudah cukup aktif dalam melaksanakan perlindungan anak yang dieksploitasi secara ekonomi, dengan mengadakan razia, pembinaan dan pelatihan. Kendala yang ditemukan, adalah kendala yang terbilang klasik yaitu: sifat dari anak, keluarga, nilainilai agama yang luntur, pendidikan, lingkungan masyarakat, masalah ekonomi, pergeseran budaya, fasilitas pembinaan anak yang kurang, sumber daya manusia yang kurang, dan dana yang kurang memadai. Penulis mengharapkan kedepannya, agar anak lebih diperhatikan oleh Pemerintah Kota Padang serta Masyarakat dan Keluarga anak.
\end{abstract}

Kata kunci: anak, dinsosnaker, ekonomi, padang, eksploitasi

\section{Latar Belakang}

Sebagai amanah dan sekaligus karunia dari Tuhan Yang Maha Esa, anak senantiasa harus dijaga karena dalam dirinya melekat harkat, martabat dan hak-hak sebagai manusia yang harus dilindungi. Hak anak merupakan bagian dari Hak Asasi Manusia (HAM) yang terbuat dalam Undang-Undang Dasar 1945 dan Undang-Undang Nomor 39 Tahun 1999 tentang Hak Asasi Manusia, serta konvensi PBB tentang Hak Anak dari sisi kehidupan berbangsa dan bernegara. Sehingga negara 
berkewajiban melindungi setiap anak atas kelansungan hidup, tumbuh dan berkembang, berpartisipasi dalam perlindungan dari tindak kekerasan, diskriminasi, hak-hak sipil serta kebebasan anak.

Pada saat kita sedang menghadapi permasalahan besar tentang anak, bukan saja dalam jumlah tetapi juga karena permasalahan yang semakin kompleks ${ }^{1}$. Dahulu kita mengenal permasalahan anak hanya berkisar pada ketelantaran yang disebabkan karena ketidakmampuan untuk memenuhi kebutuhan fisik saja, sedang kebutuhan yang bersifat mental spiritual dan sosial dapat dipengaruhi oleh orang tua maupun atau masyarakat dilingkungannya. Seiring dengan perubahanperubahan yang terjadi terutama adanya arus globalisasi yang selalu membawa konsekuensi logis positif dan negatif, maka tidaklah mengherankan manakala permasalahan anak saat ini telah menjadi kompleks dan rumit.

Anak telah menjadi sasaran kepentingan bagi banyak kalangan termasuk untuk tujuan komersial yang merugikan kepentingan terbaik bagi anak ${ }^{2}$. Betapa saat ini telah terjadi semacam jaringan yang memanfaatkan anak menjadi objeknya ${ }^{3}$. Anak dijadikan objek untuk diperjual-belikan, objek kekerasan, menjadi alat oleh orang dewasa tertentu untuk mencari nafkah dijalan-jalan sebagai anak jalanan, dan sebagainya ${ }^{4}$. Perlakuan kekerasan terhadap anak itu seringkali justru terjadi dilingkungan sekitar anak itu sendiri, dimana seharusnya anak memperoleh perlindungan. Itulah gambaran yang kurang menggembirakan bagi potret kehidupan anakanak.

Oleh karenanya penghargaan akan hak-hak yang melekat pada anak tetaplah harus dikedepankan dalam segala waktu, tempat maupun personality pengedepanan prinsip-prinsip non diskriminasi; kepentingan terbaik untuk anak; hak untuk hidup; kelansungan dan perkembangan, penghargaan terhadap pendapat anak, tidaklah dapat ditawar-tawar lagi harus senantiasa menyertai anak-anak tersebut. Untuk itu idealisme penciptaan lingkungan yang mendukung tumbuh kembang bagi anak sebagaimana tercermin dari hasil-hasil penelitian, deklerasi UN-GASS (United Nations General Assembly for Spesial Section) on Children dan Konvensi Hak-hak Anak tersebut diatas setidaknya telah sejalan (inline) dengan prinsip-prinsip Agenda 21 KTT Bumi Rio De Janeiro tahun 1992 untuk Pembangunan Berkelanjutan

1 Choirun Nisak Aulina, "Penanaman Disiplin Pada Anak Usia Dini", Jurnal Pedagogia Vol. 2 No. 1 (Februari 2013): 36.

2 Andriyani Mustika Nurwijayati, "Eksploitasi Anak: Perlindungan Hukum Anak Jalanan Dalam Perspektif Hukum Pidana Di Daerah Yogyakarta”, Jurnal Jurisprudence Vol. 1 No. 1 (Juli 2012): 208.

3 Benedhicta Desca Prita Octalina, "Perlindungan Hukum Terhadap Anak Korban Eksploitasi Ekonomi”, Jurnal Skripsi Ilmu Hukum Program Kekhususan Peradilan dan Penyelesaian Sengketa Hukum, (Yogyakarta: Fakultas Hukum Universitas Atmajaya, 2014), Tidak Dipublikasikan, hlm. 3.

4 Netty Endrawati, "Perlindungan Hukum Terhadap Pekerja Anak Di Sektor Informal (Studi Kasus Di Kota Kendiri)", Disertasi Ilmu Hukum, Program Pasca Sarjana Dotor Ilmu Hukum, (Surabaya: UNTAG, 2011), Tidak Dipublikasikan, hlm. 13. 
(suistanable development) yang secara eksplisit menegaskan bahwa anak dan remaja sebagai salah satu kelompok utama-Major Group yang dilibatkan untuk melindungi lingkungan dan kegiatan masyarakat yang sesuai dan berkelanjutan. Kesadaran akan pentingnya penciptaan lingkungan yang layak bagi anak dipertegas dalam konferensi Habitat II atau City summit, Istanbul, Turki tahun 1996 paragraf 13, pembukaanya menegaskan bahwa anak dan remaja harus mempunyai tempat tinggal yang layak; terlibat dalam proses pengambilan keputusan, baik di kota maupun di komunitas; terpenuhi kebutuhan dan peran anak dalam bermain di komunitasnya ${ }^{5}$.

Sebagai negara yang telah menyatakan ikut menegakkan komitmen terhadap hak-hak anak dengan meratifikasi konvensi Hak Anak melalui keputusan Presiden Republik Indonesia Nomor 36 Tahun 1990, terkandung bahwa Indonesia berserta seluruh elemen didalamnya ikut ambil bagian dalam melaksanakan kewajiban terhadap anak dengan memberikan, melindungi dan menghargai anak sebagai kebutuhan dasar setiap anak dalam wilayah yurisdiksinya. Komitmen ini kemudian diterjemahkan sebagai upaya legislasi dengan membentuk dan mengesahkan Undang-undang Nomor 23 Tahun 2002 Tentang Perlindungan Anak, yang kemudian pada tahun 2014 disempurnakan sesuai dengan kebutuhan dan perkembangan perlindungan anak di Indonesia, dengan Undang-undang Nomor 35 Tahun 2014 Tentang Pengganti Undang-Undang Nomor 23 Tahun 2002 Tentang Perlindungan Anak.

Dalam upaya meningkatkan perhatian dan kepekaan masyarakat terhadap kebutuhan dan hak anak. Pemerintah berinsiatif melahirkan wacana kota layak anak yang merupakan wujud kepedulian yang mendalam terhadap kondisi anak di Indonesia. Pada tanggal 11 Januari 2005, Presiden Republik Indonesia pada waktu Susilo Bambang Yudhoyono menandatangani Peraturan Presiden Nomor 7 tahun 2005 tentang rencana pembangunan jangka menengah sosial tahun 2004-2009. Pada Bab 12 lampiran Perpres (peningkatan kualitas kehidupan dan peran perempuan serta kesejahteraan dan perlindungan anak, khususnya pada program peningkatan kesejahteraan dan perlindungan) pemerintah bertujuan meningkatkan kesejahteraan anak dan mewujudkan anak Indonesia yang sehat, cerdas, ceria dan berakhlak mulia, serta melindungi anak terhadap berbagai bentuk kekerasan, eksploitasi, diskriminasi. Untuk program meningkatkan kesejahteraan dan perlindungan anak dikembangkan kegiatan pokok sebagai berikut ${ }^{6}:$ 1) Pengembangan berbagai kebijakan dan peraturan perundangundangan dalam rangka pemenuhan ahak anak, terutama bidang pendidikan,

5 BPMPKB Kota Padang, Laporan Pelaksanaan Kota Padang Sebagai Kota Layak Anak Tahun 2015, (Padang: Badan Pemberdayaan Masyarakat, Perempuan dan Keluarga Berencana, 2015), hlm. 1.

6 BPMPKB Kota Padang, Laporan Pelaksanaan Kota Padang Sebagai Kota Layak Anak Tahun 2014, (Padang: Badan Pemberdayaan Masyarakat, Perempuan dan Keluarga Berencana, 2014), hlm. 2. 
kesehatan, sosial, hukum, ketenagakerjaan;

2) Pelaksana komunikasi, informasi dan edukasi peningkatan kesejahteraan dan perlindungan anak; 3) Pelaksanaan kebijakan anak dan peraturan perundang-undangan untuk menjamin dan melindungi hak anak; 4) Meningkatakan upaya dalam rangka pemenuhan hak-hak anak, seperti penyediaan akta kelahiran dan penyediaan ruang publik yang aman dan nyaman untuk bermain anak; dan 5) Pengembangan mekanisme perlindungan bagi anak dalam perlindungan khusus.

Dalam mewujudkan kebijakan dalam rangka pemenuhan hak anak merupakan suatu proses yang panjang dan perlu diupayakan. Mengingat masih banyak permasalahan anak yang belum kunjung selesai. Untuk menjawab tantangan tersebut, pemerintah pusat melalui Deputi Perlindungan Anak Kementerian Pemberdayaan Perempuan dan Perlindungan Anak Republik Indonesia menyusun kebijakan dan program peningkatan kesejahteraan perlindungan anak, salah satunya dengan menginisiasikan kebijakan Kota Layak Anak. Kota Layak Anak yang selanjutnya disebut KLA adalah sistem pembangunan satu wilayah administrasi yang mengintegrasikan komitmen dan sumber daya pemerintah, masyarakat dan dunia usaha yang terancam secara menyeluruh dan berkelanjutan dalam program dan kegiatan pemenuhan hak anak. Untuk mendukung kebijakan tersebut maka Menteri

7 Ibid.

8 Ibid.
Pemberdayaan Pemberdayaan Republik Indonesia baru-baru ini telah mengeluarkan Peraturan Menteri Pemberdayaan Perempuan Republik Indonesia Nomor 2 Tahun 2009 tentang Kebijakan KLA. Kebijakan tersebut dimaksudkan untuk memberikan pedoman bagi penyelenggaraan pembangunan kota melalui pengintegrasian komitmen dan sumber daya pemerintah, masyarakat dan dunia usaha yang secara menyeluruh dan berkelanjutan untuk memenuhi hak anak melalui strategi pengarusatamaan Hak Anak (PUHA) ${ }^{7}$.

Kota Padang sebagai ibukota dari Provinsi Sumatera Barat pada tahun 2009 telah diberi penghargaan oleh Pemerintah Pusat melalui Menteri Negara Pemberdayaan Perempuan dan Perlindungan Anak sebagai Kota Padang menuju Kota Layak Anak dengan Indikator keberhasilan seperti zona selamat sekolah, taman bermain, taman baca, bina keluarga balita, pendidikan anak usia dini (paud), pustaka keliling, kantin kejujuran sekolah dan sebagainya. Oleh karena itu Pemerintah Kota Padang dengan penghargaan tersebut akan tetap untuk meninggkatakan Padang menjadi Kota Layak Anak dengan icon Padang Kota Ramah Anak dengan pola $5 \mathrm{~S}$, yaitu: senyum, sapa, salam, sopan dan santun. Pada tahun 2012 dan tahun 2013 kembali menerima penghargaan Kota Layak Anak Tingkat Madya dari Menteri Pemberdayaan Perempuan dan Perlindungan Anak Republik Indonesia, yang diserahkan pada tanggal 4 Oktober 2012 dan Juli $2013^{8}$. 
Untuk mendukung perlindungan anak ini, Kota Padang juga telah mengeluarkan Peraturan Daerah Kota Padang nomor 2 tahun 2012 tentang Pembinaan dan Perlindungan Anak. Dimana Pasal 7, dinyatakan bahwa kewajiban dan tanggung jawab perlindungan anak adalah kewajiban dan tanggung jawab bersama:a) Pemerintah Daerah; b) masyarakat; c) keluarga dan orang tua; d) dunia usaha dan e) lembaga adat, media massa, keagamaan dan lembaga lainnya ${ }^{9}$.

Terhadap peran Pemerintah Daerah, Pasal 8 menjelaskan bahwa Pemerintah Daerah berkewajiban dan bertanggung jawab untuk: a) menghormati dan menjamin hak asasi anak tanp membedakan suku, agama, ras, golongan, jenis kelamin, etnik, budaya dan bahasa, status hukum anak, urutan kelahiran anak, kondisi fisik dan mental anak; b) memberikan dukungan sarana dan prasarana dalam penyelengaraan pembinaan dan perlindungan anak; c) menjamin pembinaan dan perlindungan, pemeliharaan dan kesejahteraan anak dengan memperhatikan hak dan kewajiban orang tua, wali atau orang lain dan secara lingkungan betanggung jawab terhadap anak; d) mengawasi penyelengaraan perlindungan anak; dan e) menjamin anak untuk mempergunakan haknya dalam menyampaikan pendapat sesuai dengan usia dan tingkat kecerdasan anak.

Perkembangan sekarang ini di kota Padang masih banyaknya anak yang mengemis dan mengamen di lampu lalu lintas, masih banyaknya anak yang tidur di pasar dan tidak pulang kerumahnya, masih banyaknya ditemukan anak-anak yang tidak bersekolah namun malah berkeliaran di pasar atau dijalanan kota Padang ${ }^{10}$. Pada Pasal 37 ayat (1) berbunyi Pemerintah Daerah, penegak hukum, LSM, atau organisasi sosial dan masyarakat berkewajiban dan bertanggung jawab memberi perlindungan bagi anak yang memerlukan perlindungan khusus dan ayat (2) menyebutkan perlindungan khusus sebagaimana dimana dimaksud ayat (1) diberikan pada anak dalam situasi darurat, anak yang berhadapan dengan hukum, anak dari kelompok minoritas dan terisolasi, anak yang dieksploitasi secara ekonomi dan/ seksual, anak yang menjadi penyalahgunaan narkotika, alkohol, psikotropika dan zat adikti lainnya (NAPZA), anak korban penculikan, penjualan, perdagangan, anak korban kekerasan fisik dan/ mental, anak yang menyandang cacat dan anak korban pelakuan

9 Peraturan daerah ini bertujuan untuk memberikan perlindungan terhadap anak-anak di kota Padang, mengingat keberadaan anak bisa menjadi sasaran eksploitasi, tindak kekerasan dan kesewenang-wenangan sehingga perlu dilakukan penanganan secara komprehensif, terpadu dan berkesinambungan. Ini bisa dilihat dalam Pasal 3 perda ini yang menyebutkan bahwa pembinaan dan perlindungan anak betujuan: a) untuk menjamin terpenuhinya hak anak agar dapat hidup, tumbuh, berkembang dan berpartisipasi secara optimal sesuai dengan harkat martabat kemanusiaan, demi terwujudnya anak yang berkualitas, berakhlak, mulia dan sejahtera; dan b) membentuk karakter anak berdasarkan falsafah adat basandi sarak, sarak basandi kitabbullah sesuai denga filosofi adat alam minangkabau. Kenyataannya hak anak belum sepenuhnya belum dipenuhi pemerintah kota Padang.

10 Minangkabaunews, "Sosialisasi Perda Nomor 1 tentang Pembinaan Anak Jalanan, Gelandangan, Pengemis dan Pedagang Asongan”, http://minangkabaunews.com/artikel-2874-sosialisasi-perda-nomor-1-tentangpembinaan-anak-jalanan-gelandangan-pengemis-dan-pedagang-asonganda.html, diakses 2 Desember 2015. 
salah dan penelantaran. Sedangkan pada ayat (3) menjelaskan bahwa upayaya perlindungan khusus sebagaimana dimaksud pada ayat (2) adalah berupa pengawasan, perlindungan, perawatan, rehabilitas. Selanjutnya pada ayat (4) menjelaskan upaya sebagaimana dimaksud pada ayat (3) dilaksanakan oleh keluarga, LSM dan Pemerintah Daerah.

Terhadap anak-anak gelandangan, pengemis dan pengamen Dinas Sosial dan Tenaga Kerja Kota Padang berhak untuk melaksanakan penertiban, selain itu perlindungan anak yang dieksploitasi secara ekonomi juga dapat direalisasikan. Dinas Sosial dan Tenaga Kerja Kota Padang bekerjasama dengan Polisi Pamong Praja Kota Padang untuk merazia anak-anak tersebut, kemudian anak-anak tersebut ditampung, dibina dan diberikan pelatihan-pelatihan, agar anak-anak tersebut tidak kembali lagi ke jalanan.

Berdasarkan uraian diatas terlihat maka penulis tertarik untuk membahas lebih dalam, tentang peran Dinas Sosial dan Tenaga Kerja Kota Padang dalam pelaksanaan perlindungan khusus hak-hak anak oleh Pemerintah Daerah Kota Padang yang tercantum dalam ketentuan peraturan daerah tentang perlindungan terhadap hak-hak anak yang dibatasi terhadap perlindungan khusus anak yang dieksploitasi secara ekonomi, dengan merumuskan masalah dalam bentuk pertanyaan-pertanyaan sebagai berikut ini.
1. Bagaimana peran Dinas Sosial dan Tenaga Kerja Kota Padang dalam melaksanakan perlindungan hak anak yang dieksploitasi secara ekonomi.

2. Apa kendala-kendala Dinas Sosial dan Tenaga Kerja Kota Padang dalam melaksanakan perlindungan hak anak yang dieksploitasi secara ekonomi.

Metode yang digunakan dalam penelitian ini adalah metode penelitian socio legal (sociolegal research). Yang mana menempatkan hukum sebagai gejala sosial, dalam hal demikian hukum dipandang dari segi luarnya saja. Oleh karena itu dalam peneltian socio legal hukum selalu dikaitkan dengan masalah sosial ${ }^{11}$. Dimana dalam penelitian ini menitikberatkan pada peran Dinas Sosial Dan Tenaga Kerja Kota Padang dalam kaitanya dengan hukum, terutama dengan menjalankan penegakan perlindungan hukum terhadap anak yang tereksploitasi secara ekonomi.

\section{Pembahasan}

\section{A. Peran Dinas Sosial Dan Tenaga Kerja Kota Padang Dalam Melaksanakan Perlindungan Hak Anak Yang Dieksploitasi Secara Ekonomi}

Menurut data BPS Kota Padang berdasarkan hasil sensus penduduk tahun 2010, proporsi jumlah anak usia 0-18 tahun sesuai Undang-Undang Perlindungan Anak dari seluruh penduduk Kota Padang populasi

11 Peter Mahmud Marzuki, Penelitian Hukum, Cetakan Ke-7, (Jakarta: Kencana Media Group, 2011), hlm. 87. 
Tabel 1. Data Populasi Anak (Sumber dari BPMPKB ${ }^{12}$ )

\begin{tabular}{|c|l|c|c|c|}
\hline No & \multicolumn{1}{|c|}{ Kecamatan } & Laki-Laki & Perempuan & Jumlah \\
\hline 1 & Padang Selatan & 10.586 & 10.187 & 20.773 \\
\hline 2 & Padang Timur & 13.187 & 12.584 & 25.771 \\
\hline 3 & Padang Barat & 7.244 & 6.897 & 14.141 \\
\hline 4 & Padang Utara & 9.605 & 9.913 & 19.518 \\
\hline 5 & Koto Tangah & 31.766 & 30.120 & 61.886 \\
\hline 6 & Nanggalo & 9.553 & 9.201 & 18.754 \\
\hline 7 & Kuranji & 24.237 & 22.882 & 47.119 \\
\hline 8 & Pauh & 10.590 & 10.162 & 20.752 \\
\hline 9 & Lubuk Kilangan & 9.711 & 9.139 & 18.850 \\
\hline 10 & Lubuk Begalung & 4.947 & 18.747 & 38.784 \\
\hline 11 & Bungus & 151.456 & 144.307 & 29.415 \\
\hline & Kota Padang & & & \\
\hline
\end{tabular}

Sumber: BPMPKB Kota Padang, 2015

anak yang tersebar di Kecamatan dapat dilihat pada Tabel 1.

Jika dilihat dari data diatas persebaran jumlah anak-anak yang berumur 0-18 tahun yang paling banyak berada di Kecamatan Koto Tangah, Kuranji dan Lubuk Begalung, sementara penduduk anak-anak yang paling sedikit berada pada Kecamatan Bungus. Dari persebaran data di atas terlihat jenis kelamin anak laki-laki lebih banyak dibandingkan anak perempuan ${ }^{13}$.

Tugas Pokok dari Dinas Sosial dan Tenaga Kerja Kota Padang sendiri adalah melaksanakan urusan Pemerintah Daerah di Bidang Sosial dan Tenaga Kerja serta tugas perbantuan. Hal ini berarti bahwa Dinas sosial dan Tenaga Kerja Kota Padang melayani seluruh permasalahan sosial dan tenaga kerja yang ada. Selain sebagai perpanjangan tangan pemerintah pusat, Dinas Sosial dan Tenaga Kerja Kota Padang juga merupakan perpanjangan tangan dari Pemerintah Provinsi Sumatera Barat. Hal ini dapat terlihat dari beberapa kegiatan yang didanai oleh pemerintah pusat melalui DIPA yang ada di Pemerintah Provinsi Sumatera Barat ${ }^{14}$.

Terhadap perlindungan anak yang terkesploitasi secara ekonomi termasuk dalam Bidang Pelayanan dan Rehabilitasi Sosial. Hal ini senada dengan perintah Pasal (9) ayat

12 BPMPKB Kota Padang, Laporan Pelaksanaan Kota Padang Sebagai Kota Layak Anak Tahun 2013, (Padang: Badan Pemberdayaan Masyarakat, Perempuan dan Keluarga Berencana, 2013), hlm. 7.

13 Ibid.

14 Dinsosnaker Kota Padang, Rencana Strategis Tahun 2014-2019, (Padang: Dinas Sosial dan Tenaga Kerja Kota Padang Tahun, 2014), hlm. 12. 
1 Peraturan Walikota Padang Nomor 29 Tahun 2008 Tentang Penjabaran Tugas Pokok Dan Fungsi Dinas Sosial Dan Tenaga Kerja, bahwa Bidang Pelayanan Jasa dan Rehabilitasi Sosial dipimpin oleh seorang Kepala Bidang yang dalam melaksanakan tugasnya berada dibawah dan bertanggung jawab kepada Kepala Dinas. Bidang Pelayanan dan Rehabilitasi Sosial mempunyai tugas membantu Kepala Dinas dalam menyiapkan bahan kebijaksanaan teknis, pelayanan kesejahteraan sosial anak, remaja, lansia, pelayanan dan rehabilitasi sosial penyandang cacat dan rehabilitasi tuna sosial dan korban napza ${ }^{15}$.

a. Bidang Pelayanan dan Rehabilitasi Sosial mempunyai fungsi ${ }^{16}$ :

b. Merumuskan kebijakan teknis pelayanan dan rehabilitasi sosial penyandang cacat, kesejahteraan sosial anak, remaja dan lanjut usia, korban napza dan tuna sosial;

c. Melaksanakan kebijakan teknis pelayanan dan rehabilitasi sosial penyandang cacat, kesejahteraan sosial anak, remaja, dan lanjut usia, serta korban napza dan tuna sosial berdasarkan ketentuan peraturan perundang-undangan;

d. Menyusun pedoman, standar pelayanan panti-panti pemerintah serta kriteria dan prosedur teknis rehabilitasi sosial penyandang cacat, kesejahteraan sosial anak, remaja, dan lanjut usia, serta korban napza dan tuna sosial;

15 Ibid., hlm. 19.

16 Ibid., hlm. 20-21. e. Melakukan pembinaan teknis pelayanan, rehabilitasi sosial penyandang cacat serta yayasan yang bergerak dibidang usaha kesejahteraan sosial anak remaja, dan lanjut usia, serta korban napza dan tuna sosial;

f. Melaksanakan evalusai kebijakan teknis pelayanan rehabilitasi sosial penyandang cacat, kesejahteraan sosial anak remaja, dan lanjut usia, serta korban napza dan tuna sosial;

g. Membuat evaluasi dan laporan pelaksanaan tugas bidang pelayanan dan rehabilitasi sosial; dan

h. Melaksanakan tugas kedinasan lain yang diberikan oleh atasan sesuai dengan tugas dan fungsinya.

Lebih jauh lagi terhadap perlindungan anak yang tereksploitasi secara ekonomi ini, bisa dilihat didalam Paragraf 1 (satu) yang membahas mengenai Seksi Pelayanan Kesejahteraan Sosial Anak dan Lanjut Usia yaitu Pasal (10) ayat 1-3 Peraturan Walikota Padang Nomor 29 Tahun 2008 Tentang Penjabaran Tugas Pokok Dan Fungsi Dinas Sosial Dan Tenaga Kerja, sebagai berikut:

1. Seksi Pelayanan Kesejahteraan Sosial Anak dan Lanjut Usia dipimpin oleh seorang Kepala Seksi Pelayanan Kesejahteraan Sosial Anak dan Lanjut Usia yang dalam melaksanakan tugasnya berada dibawah dan bertanggung jawab 
kepada Kepala Bidang Pelayanan dan Rehabilitasi Sosial.

2. Seksi Pelayanan Kesejahteraan Sosial Anak dan Lanjut Usia mempunyai tugas menyusun bahan identifikasi sasaran penanggulangan masalah sosial, pelaksanaan kegiatan di bidang sosial yang meliputi pelayanan kesejahteraan sosial anak, balita terlantar, anak terlantar, dan lanjut usia potensial terlantar, rehabilitasi sosial anak nakal, rehabilitasi sosial anak jalanan serta rehabilitasi sosial anak cacat.

3. Adapun tugas Seksi Pelayanan Kesejahteraan Sosial Anak dan Lanjut Usia adalah sebagai berikut:

a. Mengumpulkan data dan bahan tentang Pelayanan Kesejahteraan Sosial Anak Balita, Anak Terlantar, Anak Jalanan, Anak Nakal, Remaja dan Lanjut Usia;

b. Menyiapkan Bahan tentang Pelayanan Kesejahteraan Sosial Anak Balita, Anak Terlantar, Anak Jalanan, Anak Nakal, Remaja dan Lanjut Usia;

c. Menyiapkan pedoman dan petunjuk teknis tentang Pelayanan Kesejahteraan Sosial Anak Balita, Anak Terlantar, Anak Jalanan, Anak Nakal, Remaja dan Lanjut Usia;

d. Membuat rencana dan program kerja seksi pelayanan Kesejahteraan Sosial Anak, Remaja dan Lanjut Usia; e. Melaksanakan koordinasi dengan unit kerja dalam pelaksanaan kegiatan;

f. Menyiapkan bahan pemberian bantuan Anak Balita, Anak Terlantar, Anak Jalanan, Anak Nakal, Remaja dan Lanjut Usia;

g. Memberikan bimbingan dan pembinaan pelayanan Anak Balita, Anak Terlantar, Anak Jalanan, Anak Nakal, Remaja dan Lanjut Usia;

h. Memberikan izin pengangkatan anak antar Warga Negara Indonesia;

i. Melaksanakan jaminan sosial bagi lanjut usia tidak potensial terlantar;

j. Melaksanakan penyiapan berkas kerja, data dan bahan menurut ketentuan berlaku;

k. Melaksanakan pengetikan persuratan Seksi Pelayanan Kesejahteraan Sosial Anak, Remaja dan Lanjut Usia;

1. Menyusun laporan pelaksanaan tugas dan kegiatan Seksi Pelayanan Kesejahteraan Sosial Anak, Remaja dan Lanjut Usia;

m. Melaksanakan tugas lain yang diberikan oleh atasan sesuai dengan tugas dan fungsinya.

Menurut MM. Dt. Bandaro Dinas Sosial dan Tenaga Kerja Kota Padang selalu berusaha untuk memberantas anak yang dieksploitasi secara ekonomi. Hal ini bisa dilhat dari beberapa upaya yang dilakukan oleh Dinas 
Sosial dan Tenaga Kerja Kota Padang, antara lain ${ }^{17}$ :

1. Dinas Sosial dan Tenaga Kerja Kota Padang selalu berkoodinasi dengan Kementerian Sosial antara lain hal ini yang selalu bersinergi dengan komitmen kementerian sosial, yaitu ${ }^{18}$ :

a. Perlindungan Anak, yaitu Segala kegiatan untuk menjamin dan melindungi anak dan hak-haknya agar dapat hidup, tumbuh, berkembang, dan berpartisipasi, secara optimal sesuai dengan harkat dan martabat kemanusiaan serta mendapat perlindungan dari kekerasan dan diskriminasi;

b. Perlindungan Khusus, yaitu Perlindungan yang diberikan kepada anak dalam situasi darurat, anak yang berhadapan hukum, anak dari kelompok minoritas dan terisolasi, anak yang dieksploitasi secara ekonomi dan atau seksual, anak yang diperdagangkan, anak yang menjadi korban penyalahgunaan narkotika, alkohol, psikotropika, dan zat adiktif lainnya (napza), anak korban penculikan, penjualan, perdagangan, anak korban kekerasan baik fisik, dan/ atau mental, anak yang menyandang cacat dan anak korban perlakuan salah dan penelantaran; c. Usaha Penyantunan Anak Terlantar, yaitu Usaha bimbingan dan pemeliharaan terhadap anak terlantar yang antara lain diselenggarakan melalui usaha pengangkatan anak sebagai upaya terakhir dalam usaha kesejahteraan anak;

d. Pelayanan Integratif (untuk anak), yaitu Pelayanan yang melibatkan berbagai pihak yang memiliki kompetensi dalam upaya optimalisasi proses tumbuh kembang anak dan pengembangan fungsi kelembagaan;

e. Pelayanan Kesejahteraan Sosial, yaitu serangkaian kegiatan pelayananyang diberikan terhadap individu, keluarga maupun masyarakat yang membutuhkan atau mengalami permasalahan sosial baik yang bersifat pencegahan, pengembangan,maupun rehabilitasi guna mengatasi permasalahan yang dihadapi dan/atau memenuhi kebutuhan secara memadai sehingga mereka mampu menjalankan fungsi sosialnya secara memadai (Kepmensos No. 10/Huk/2007);

f. Pelayanan Sosial, yaitu pelayanan yang ditujukan untuk membantu Penyandang Masalah Kesejahteraan Sosial dalam mengembalikan dan mengembangkan fungsi sosialnya;

17 Laurensius Arliman S, Penyuluhan Hukum Perlindungan Anak, (Padang: Sekolah Tinggi Ilmu Hukum Padang, 2015), hlm. 3. 
g. Pelayanan Sosial Anak Jalanan, yaitu Suatu proses pemberian pelayanan, perlindungan, pemulihan dan pemeliharaan taraf kesejahteraan sosial bagi anak jalanan agar memperoleh hak-hak dasarnya yaitu kelangsungan hidup, tumbuh kembang, perlindungan maupun partisipasi

h. Pelayanan Sosial Anak Terlantar, yaituProsesatau serangkaiankegiatan yang dilakukan secara terorganisir, sistematis dan profesional terhadap anak terlantar guna terpenuhinya seoptimal mungkin hak anak untuk kelangsungan hidup, tumbuh kembang, perlindungan dan partisipasi.

2. Dinas Sosial dan Tenaga Kerja Kota Padang melakukan razia dengan petugas Pamong Praja Kota Padang melakukan razia dengan Pamong Praja Kota Padang selalu dilakukan oleh Dinas Sosial dan Tenaga Kerja Kota Padang untuk meminalisir anak yang dieksploitasi secara ekonomi, ini bisa dilihat dari tertangkapnya anak yang mengamen dan mengemis dilampu merah, pertokoan, taman-taman dan tempat umum lainnya. Terhadap hal ini Dinas Sosial dan Tenaga Kerja Kota Padang melakukan ${ }^{19}$ :

a. Anak jalanan yang tertangkap dan masih berstatus anak sekolah, maka akan diberikan surat perjanjian dengan Dinas Sosial dan Tenaga Kerja Kota Padang, hal ini dilaksanakan agar tidak mengulangi perbuatnnya dan mengutamakan sekolah;

b. Anak jalan yang tertangkap dan berdomisili di luar Kota Padang, akan dikembalikan ke daerah asalnya dan dibuat surat perjanjian, hal ini dilakukan agar menimbulkan efek jera, sehingga anak tidak melakukan perbuatannya kembali;

c. Anak yang tertangakap ternyata memiliki sistem berorganisasi, maka pihak Dinas Sosial dan Tenaga Kerja Kota Padang akan bekerjasama dengan pihak Kepolisian Resort Kota Padang untuk mengungkapnya dan memberikannya hukuman sesuai denga atura yang berlaku, namun apabila orang tua yang menyuruh anak untuk mengamen atau mengemis, maka orang tua akan dinesehati dan diberi peringatan oleh Dinas Sosial dan Tenaga Kerja Kota Padang;

d. Jika anak yang tertangkap tidak punya orang tua, dan daerah asalnya tidak jelas, maka anak tersebut akan dititipkan di Rumah Perlindungan Sosial Anak.

3. Dinas Sosial dan Tenaga Kerja Kota Padang melakukan kerja sama dengan 
Lembagas Swadaya Masyarakat ${ }^{20}$. Dinas Sosial dan Tenaga Kerja Kota Padang juga menjalin kerjasama dengan Lembaga Swadaya Masyarakat ataupun aktivis-aktivis yang prihatin terhadap perlindungan anak khusus dieksploitasi secara ekonomi. Hal iniakan memberitahu Dinas Sosial dan Tenaga Kerja Kota Padang akan tindakan-tindakan anak, ataupun informasi-informasi terhadap perlindungan anak khusus dieksploitasi secara ekonomi. Dinas Sosial dan Tenaga Kerja Kota Padang melakukan kerjasama antara lain sebagai berikut:

a. Lembaga Swadaya Masyarakat Suci Hati;

b. Lembaga Swadaya Masyarakat Cimpago

c. Beberapa aktivis pemerhati anak.

Selain upaya diatas Dinas Sosial dan Tenaga Kerja Kota Padang juga melakukan upaya lain yang mendukung perlindungan khusus terhadap anak yang dieksploitasi secara ekonomi ini, antara lain ${ }^{21}$ :

1. Anak yang tertangkap diberikan pelatihan oleh Dinas Sosial dan Tenaga Kerja Kota Padang. Terhadap hal ini bisa dilihat dari laporan pelatihan yang telah diberikan Dinas Sosial dan Tenaga Kerja Kota Padang terhadap anak, yang dijelaskan sebagai berikut:

a. Pada tahun 2011, Dinas Sosial dan Tenaga Kerja Kota Padang melalui dana APBD Kota Padang mengalokasikan dana untuk pelatihan keterampilan service hand phone bagi anak jalanan sejumlah 15 (lima belas) orang melalui kegiatan pelatihan keterampilan dan praktek belajar kerja bagi anak jalan di rumah Perlindungan Sosial Anak (RPSA) ${ }^{22}$. Tabel 2.

b. Pada tahun 2012, Dinas Sosial dan Tenaga Kerja Kota Padang melalui dana APBD Kota Padang mengalokasikan dana untuk pelatihan keterampilan Montir Sepeda Motor bagi anak jalanan sebanyak 20 (dua puluh) orang melalui kegiatan pelatihan keterampilan dan praktek belajar kerja bagi anak jalan di rumah Perlindungan Sosial Anak (RPSA) ${ }^{23}$. Tabel 3.

c. Pada tahun 2013, Dinas Sosial dan Tenaga Kerja Kota Padang melalui dana APBD Kota Padang mengalokasikan dana untuk pelatihan keterampilan Montir Sepeda Motor bagi anak jalanan sebanyak 15 (lima belas) orang melalui kegiatan

20 Ibid., hlm. 5.

21 Ibid.

22 Dinas Sosial Dan Tenaga Kerja Kota Padang, Laporan Pelatihan Service Hand Phone Bagi Anak Jalanan Kegiatan Pelatihan Keterampilan Dan Praktek Belajar Kerja Anak Jalanan Di Rumah Perlindungan Sosial Anak, (Padang: Dinas Sosial Dan Tenaga Kerja Kota Padang, 2011), hlm. 1-5.

23 Dinas Sosial Dan Tenaga Kerja Kota Padang, Laporan Pelatihan Keterampilan Montir Sepeda Motor Bagi Anak Jalanan Kegiatan Pelatihan Keterampilan Dan Praktek Belajar Kerja Anak Jalanan Di Rumah Perlindungan Sosial Anak, (Padang: Dinas Sosial Dan Tenaga Kerja Kota Padang, 2012), hlm. 1-4. 
Tabel 2. Daftar Anak Yang Mengikuti Pelatihan Keterampilan Service Hand Phone Tahun 2011 24

\begin{tabular}{|c|l|c|l|}
\hline No & Nama & Pendidikan & \multicolumn{1}{c|}{ Alamat } \\
\hline 1 & SR & SMP & Jl. Aur Duri Indah, No. 16 \\
\hline 2 & RW & SMA & Jl. Gadjah Mada, No. 18 \\
\hline 3 & FR & SMA & Komp. Taruko I/B No. 21 \\
\hline 4 & SJN & SMP & Jati Rumah Gadang No. 52 \\
\hline 5 & RF & SMA & Komp. Taruko I Z/10 \\
\hline 6 & YDP & SMA & Gurun Laweh Nanggalo \\
\hline 7 & AH & SMP & Gurun Laweh Nanggalo \\
\hline 8 & A & SMP & Jl. Samudera 23, Padang \\
\hline 9 & YS & SMP & Jl. Unjung Pandan, No 39 \\
\hline 10 & GA & SMA & Jl. Samudera 48, Padang \\
\hline 11 & YS & SMP & Simp. Kopertis Wil. X No.3 \\
\hline 12 & DMP & SMP & Jati Rumah Gadang, No. 11 \\
\hline 13 & IAP & SMA & Jl. Alai Barat, No. 15 \\
\hline 14 & DS & SMP & Komp. Villa Bukit Indah 9 \\
\hline 15 & IMP & SMP & Komp Bukit Permai H/11 \\
\hline
\end{tabular}

Sumber: Dinas Sosial Dan Tenaga Kerja Kota Padang, 2015

pelatihan keterampilan dan praktek belajar kerja bagi anak jalan di rumah Perlindungan Sosial Anak (RPSA) ${ }^{25}$. Tabel 4.

d. Pada tahun 2014, Dinas Sosial dan Tenaga Kerja Kota Padang melalui dana APBD Kota Padang mengalokasikan dana untuk pelatihan keterampilan service hand phone bagi anak jalanan sejumlah 15 (lima belas) orang melalui kegiatan pelatihan keterampilan dan praktek belajar kerja bagi anak jalan di rumah Perlindungan Sosial Anak (RPSA) ${ }^{26}$. Tabel 5.

2. Kota Padang menyediakan Lembaga Penyelengaraan Kesejahteraan Sosial Anak Berhadapan Dengan Hukum (LPKS ABH) LPKS ABH ini difokuskan terhadap 16 (enam belas) Penyandang Kejahatan Sosial. Tempat ini disediakan oleh Kota Padang dengan bekerjasama dengan Kementerian Sosial. Diharapkan kedepannya LPKS ABH ini akan menjadi

24 Ibid.

25 Dinas Sosial Dan Tenaga Kerja Kota Padang, Laporan Pelatihan Keterampilan Montir Sepeda Motor Bagi Anak Jalanan Kegiatan Pelatihan Keterampilan Dan Praktek Belajar Kerja Anak Jalanan Di Rumah Perlindungan Sosial Anak, (Padang: Dinas Sosial Dan Tenaga Kerja Kota Padang, 2013), hlm. 1-4.

26 Dinas Sosial Dan Tenaga Kerja Kota Padang, Laporan Pelatihan Service Hand Phone Bagi Anak Jalanan Kegiatan Pelatihan Keterampilan Dan Praktek Belajar Kerja Anak Jalanan Di Rumah Perlindungan Sosial Anak, (Padang: Dinas Sosial Dan Tenaga Kerja Kota Padang, 2014), hlm. 1-4. 
Tabel 3. Daftar Anak Yang Mengikuti Pelatihan Keterampilan Montir Sepeda Motor Tahun $2012^{27}$

\begin{tabular}{|c|l|l|}
\hline No & Nama & \\
\hline 1 & TA & Jl. Samudera 86 B \\
\hline 2 & FF & Jl. Samudera 90 A \\
\hline 3 & DH & Jl. Samudera 88 C \\
\hline 4 & RR & Jl. Samudera 72 c \\
\hline 5 & DP & Jl. Belakang TMP Lolong \\
\hline 6 & AG & Jl. Samudera \\
\hline 7 & S & Jl. Limau Manis G/10 \\
\hline 8 & RAP & Jl. Limau Manis 6 \\
\hline 9 & HF & Jl. Banuaran RT 6 RW 15 Lubeg \\
\hline 10 & HM & Jl. Banuaran RT 13 RW 4 No 33 Lubeg \\
\hline 11 & I & RT 3 RW 5 Kec. Padang Timur \\
\hline 12 & AS & Jl. Jati Tanah Tinggi No. 67 \\
\hline 13 & AY & Jl. Samudera No. 88 E \\
\hline 14 & OS & Koto Luar \\
\hline 15 & AS & Limau Manis \\
\hline 16 & DF & Jl. Samudera \\
\hline 17 & RS & Parak Laweh Lawang \\
\hline 18 & DMT & Parak Laweh Lawang \\
\hline 19 & FR & Parak Laweh Lawang \\
\hline 20 & A & Parak Laweh Lawang \\
\hline & & \\
\hline
\end{tabular}

Sumber: Dinas Sosial Dan Tenaga Kerja Kota Padang, 2015

gedung yang serbaguna, demi upaya mendukung perlindungan terhadap anak di Kota Padang.

3. Kota Padang juga menyiapkan Kawasan Desa Kumenanti. Kawasan Desa Kumenanti ini diharapkan menjadi tempat yang berfungsi untuk mengatasi anak-anak yang tereksploitasi secara ekonomi. Kawasan Desa Kumenanti ini adalah sebuah program rumah layak yang diberikan kepada anak jalanan, gelandangan dan pengamen, serta pegemis. Anak-anak ini dibekali dan dididik serta diberikan keterampilan, sehingga nanti apabila kembali ke daerah asal mereka maka anak-anak akan bisa mempergunakan keahliannya tadi untuk mendapatkan uang, sehingga tidak kembali menjadi anak jalanan, gelandangan dan pengamen, serta pengemis.

4. Pembinaan Anak Jalanan, Gelandangan Dan Pengamen, Serta Pengemis Secara Lansung Kedaerahnya Anak jalanan, 
Tabel 4. Daft ar Anak Yang Mengikuti Pelatihan Keterampilan Montir Sepeda Motor Tahun $2013^{28}$

\begin{tabular}{|c|l|l|}
\hline No & \multicolumn{1}{|c|}{ Nama } & \multicolumn{1}{c|}{ Alamat } \\
\hline 1 & FD & Jl. Sarang Gagak \\
\hline 2 & RP & Jl. Taruko I Blok Z 10 \\
\hline 3 & SM & Jl. Aur Duri Indah, VII A/16 E \\
\hline 4 & EP & Jl. Sarang Gagak \\
\hline 5 & IF & Jl. M. Yunus \\
\hline 6 & J & Padang Teater \\
\hline 7 & AP & Jl. Sisinga Mangaraja No. 7A \\
\hline 8 & R & Jl. Sarang Gagak \\
\hline 9 & IS & Taruko 1, Blok B 15 \\
\hline 10 & RA & Jl. Tungang \\
\hline 11 & F & Pengambiram \\
\hline 12 & RG & Jl. Kampung Baru No. 80 \\
\hline 13 & A & Jl. Jati Rumah Gadang \\
\hline 14 & O & Jati IV No. 16 \\
\hline 15 & M & Gurun Laweh \\
\hline
\end{tabular}

Sumber: Dinas Sosial dan Tenaga Kerja Kota Padang, 2015

gelandangan dan pengamen, serta pengemis yang terdata di kelurahan ataupun kecamatan, Dinas Sosial dan Tenaga Kerja Kota Padang bersama Tenaga Kesejahteraan Sosial Kecamatan Pekerja Sosial Masyarakat (TKSK PSM) Kota Padang, akan turun lansung, kemudian memberikan pengarahan, nasehat serta pelatihan-pelatihan keahlian berdasarkan bakat dan minat, yang nantinya berguna bagi anakanak tersebut, sehingga mengurungkan niatnya untuk kembali menjadi anak jalanan, gelandangan dan pengamen, serta pengemis.
B. Kendala Dinas Sosial dan Tenaga Kerja Kota Padang dalam Melaksanakan Perlindungan Hak Anak yang Dieksploitasi Secara Ekonomi

Untuk mewujudkan perlindungan khusus terhadap anak yang dieksploitasi secara ekonomi tidaklah mudah dan tidak sederahana. Berbagai hambatan dan tantangan dan ancaman senantiasa menghadang dalam berbgai bentuk kuantitas dan kualitasnya yang sudah barang tentu harus ditemukan jalan keluarnya. Adapun secara umum permasalahan, tantangan dan hambatan yang umumnya berada di level nasional, antara 
Tabel 5. Daftar Anak Yang Mengikuti Pelatihan Keterampilan Service Hand Phone Tahun $2014^{29}$

\begin{tabular}{|c|l|l|}
\hline No & \multicolumn{1}{|c|}{ Nama } & \multicolumn{1}{c|}{ Alamat } \\
\hline 1 & DS & Bungo Pasang \\
\hline 2 & AL & Bungo Pasang \\
\hline 3 & IW & Lubuk Mintirun \\
\hline 4 & I & Bungo Pasang \\
\hline 5 & JP & Bungo Pasang \\
\hline 6 & HTY & Parak Kopi \\
\hline 7 & DHY & Ulak Karang Utara \\
\hline 8 & BAS & Parak Kopi Utara \\
\hline 9 & EP & Pasa Gadang \\
\hline 10 & RF & Pasa Gadang \\
\hline 11 & K & Pasa Gadang \\
\hline 12 & VZ & Jl. Ujung Pandan \\
\hline 13 & DM & Jl. Ujung Pandan \\
\hline 14 & TP & Jl. Ujung Pandan \\
\hline 15 & KRJ & \\
\hline
\end{tabular}

Sumber: Dinas Sosial Dan Tenaga Kerja Kota Padang, 2015

lain $^{30}$ :

a. Norma, nilai dan sistem kepercayaan yang menjadikan anak rentan terhadap ketidakadilan dan pelanggaran Hak Asasi Manusia;

b. Masih adanya beberapa kebijakan yang diskriminatif dan patriakhi. Selama ini kebijakan dan program yang ditujukan untuk anak masih bersifat variatif dan seringkali belum menjadi prioritas pembangunan;

c. Program-program pembangunan yang selama ini dilaksanakan secara lintas sector, sektotral maupun kerjasama lintas organisasi non pemerintah masih bersifat parsial serta belum dilakukan secara menyeluruh dan terpadu;

d. Konvensi-konvensi Internasional dalam kaitan hak-hak anak yang sudah diratifikasi, belum diharmonisasikan ke dalam hukum nasioanal, regulasi regional bahkan menguasai lokal;

e. Globalisasi dan percepatan teknologi informasi, kemudahan mengakses diberbagai belahan dunia ternyata sangat memberikan peluang operasionalisasi kriminilitas terhadap anak seperti trafiking;

f. Permintaan pasar akan anak yang diperdagangkan terus meningkat oleh 
karena daya beli yang meningkat, lemahnya moral dan adanya asumsi bahwa anak-anak yang masih bersih dari segala penyakit, yang kemudian membuat orang dewasa tergiur untuk membisniskan anak-anak untuk mendapatkan keuntungan.

Selain hal diatas, berdasarkan penelitian yang telah penulis lakukan terdapat beberapa kendalan didalam pemenuhan perlindungan khusus terhadap anak yang dieksploitasi secara ekonomi, antara lain:

1. Sifat Anak

Sifat anak yang keras kepala, menjadi salah satu poin penting yang susah untuk membinanya, dimana hal ini membuat perlindungan khusus terhadap anak yang dieksploitasi secara ekonomi tidak terpenuhi. Karena setelah anak dibina dan dibimbing, namun karena sifatnya yang keras, si anak bisa kembali ke jalanan kembali ${ }^{31}$.

\section{Keluarga}

Keluarga menjadi faktor penting terhadap perlindungan khusus terhadap anak yang dieksploitasi secara ekonomi. Karena jika keluarga terutama orang tua tegas terhadap anak, maka anak tidak akan terekspoitasi secara ekonomi. Orang tua fokus terhadap perlindungan dan pemenuhan-pemenuhan hak anak, sehingga tidak menyuruh anaknya untuk menjadi anak jalanan,pengemis atapun pengamen $^{32}$.
Seharusnya keluarga, lebih memahami dan mengerti bahwa anak bukanlah milik pribadi karena pada dasarnya setiap anak adalah sebuah pribadi yang utuh yang juga memiliki hak sebagaimana individu lainnya, sehingga anak tidak dapat dijadikan tumpuan amarah atas semua permasalahan yang dialami orangtua (Domestic Based Violence). Serta lebih berhati-hati dan memberikan perhatian serta menjaga anak-anak dari kemungkinan menjadi korban kekerasan yang dilakukan oleh orang-orang di sekitar kita (Community Based Violence).

3. Nilai-nilai Agama yang Luntur

Semakin lunturnya nilai-nilai agama dari seorang anak, keluarga dan masyarakat, maka anak akan mudah untuk terpengaruh dalam hal-hal negatif, hal ini tidak telepas dari eksploitasi anak dari sisi ekonomi. Jika nilai-nilai agama tadi diayomi, tidak akan terjadi eksploitasi anak dari sisi ekonomi. Karena setiap agama apapun tidak pernah mengajarkan untuk mengeksploitasi anak dari sisi ekonomi, agama menyarankan untuk melindungi dan memenuhi hak-hak anak ${ }^{33}$.

4. Pendidikan

Pendidikan menjadi salah satu faktor penting didalam pemenuhan perlindungan khusus terhadap anak yang dieksploitasi secara ekonomi. Jika setiap orang tua, masyarakat dan anak dibekali pendidikan yang cukup, makan eksploitasi anak ini tidak akan

31 Zulnimar, di dalam Laurensius, op.cit., hlm. 6.

32 MM. Dt. Bandaro, di dalam Laurensius, Ibid., hlm. 6.

33 Zulnimar, di dalam Laurensius, Ibid., hlm. 8. 
terjadi. Karena pendidikan juga mengajarkan bahwa anak harus dilindungi, dan tidak boleh dieksploitasi secara ekonomi.

\section{Lingkungan Masyarakat}

Lingkungan tempat tinggal anak tidak mendukung agar anak mendapat perlindungan khusus tersebut. Bahkan lingkungan temapt tinggal, menjorokkan anak kedalam pergaulan-pergaulan negatif, sehinggan anak turun kejalanan menjadi pengamen dan pengemis $^{34}$.

Seharusnya masyarakat harus ebih peka dan tidak menutup mata terhadap keadaan sekitar sehingga apabila terjadi kekerasan terhadap anak di lingkungan sekitar penanganannya dapat lebih cepat guna menghindari kemungkinan yang lebih buruk pada anak yang bersangkutan.

Aparat hukum seharusnya dapat lebih peka anak pada setiap proses penanganan perkara anak baik dalam hal anak sebagai korban tindak pidana maupun anak sebagai pelaku dengan mengedepankan prinsip demi kepentingan terbaik bagi anak (the best interest for the child).

6. Masalah Ekonomi

Masalah ekonomi merupakan faktor pendukung yang membuat anak turun kejalan. Demi memenuhi kebutuhan hidupnya, anak rela menghabiskan waktu yang seharusnya digunakan untuk bersekolah dan bermain diganti untuk mencari uang, demi untuk menyambung kehidupannya dan memenuhi kehidupan keluarganya ${ }^{35}$.

Selain itu ada juga beberapa oknum yang benar-benar mengeksploitasi anak untuk kepentingan ekonomi atu denga kata lain untuk kepentingannya semata. Terhadap hal ini pemerintah harus benar-benar bersinergi dengan masyarakat untuk memberantas hal ini.

\section{Pergeseran Budaya}

Pergeseran budaya menjadikan anak kurang mengenal kehidupan yang baik. Pergesaeran budaya ini mengapa menjadi hal penting karena budaya yang hidup di negara kita, tidak ada mengajakan untuk mengeksploitasi anak secara ekonomi, budaya kita malah mengisyratkan agar menyiapkan anak untuk masa depannya kelak.
8. Fasilitas Penampungan Anak yang kurang

Fasiltas penampungan anak yang kurang, menajadin kendala tersendiri dan cukup klasik. Hal ini selalu terjadi karena kurangnya fasilitas yang diberikan oleh pemerintah Kota Padang. Seharusnya fasilitas penampungan anak yang kurang segera dibenahi, karena faktanya sekarang anak cukup membeludak di tempat penampungan anak.

Seharusnya hal ini harus segera disikapi dengan benar, pemerintah didalam Anggaran Pendapatan Belanja Daerah (APBD) 2016 harus memprioritaskan pemenuhan fasilitas tempat penampungan anak tersebut. 
9. Sumber Daya Manusia yang kurang

Sumber daya manusia baik dari Dinas Sosial dan Tenaga Kerja Kota Padang didalam melaksanakan pemenuhan perlindungan khusus anak yang dieksploitasi secara ekonomi ini sangatlah minim sekali. Sehingga tidak membuat kinerja yang maksimal.

Atas hal ini seharusnya pemerintah harus memerhatikannya secara khusus. Mengingat anak merupakan penerus dari bangsa dan negara ini, terutama penerus dari Kota Padang.

10. Dana yang kurang memadai

Dana yang kurang memadai ini merupakan persoalan klasik yang selalu muncul tiap tahun. Terhadap hal ini Kota Padang harus benar-benar serius untuk menyiapkan dan mengelola dana perlindungan khusus terhadap ini. Bahkan jika dirasa perlu Kota Padang mendatangkan tenaga ahli dalam mengelola hal ini, sehingga hal ini tidak muncul setiap tahunnya.

\section{Simpulan}

Berdasarkan hasil penelitian yang telah penulis lakukan, maka dapat disimpulkan bahwa: Pelaksanaan Perlindungan Khusus Oleh Pemerintah Kota Padang Terhadap Anak Menurut Peraturan Daerah Nomor 2 Tahun

2012 Tentang Pembinaan dan Perlindungan Anak sudah berjalan sesuai dengan aturan yang ada. Dimana Dinas Sosial dan Tenaga Kerja telah melakukan kegiatan-kegiatan yang mendukung pemberian perlindungan khusus terhadap yang diekploitasi secara ekonomi, dan bekerjasama dengan LSM dan instansi lainnya dalam pemenuhan perlindungan khusus ini. Terhadap kendala-kendala dalam pemenuhan perlindungan anak oleh Pemerintah Kota Padang terjadi karena: 1) Sifat Anak, 2) Keluarga, 3) Nilai-nilai Agama yang Luntur, 4) Pendidikan, 5) Lingkungan Masyarakat, 6) Masalah Ekonomi, 7) Pergeseran Budaya, 8) Fasilitas Penampungan Anak yang kurang, 9) Sumber Daya Manusia yang kurang, 10) Dana yang kurang memadai. Kedepannya penulis mengharapkan agar Pemerintah Daerah Kota Padang, Masyrakat dan Keluarga Anak mau bekerjasama dalam perlindungan anak yang dieksploitasi secara ekonomi ini. Agar perlindungan anka dari segi apapun dapat terwujud, karena kita harus selalu mengingat, bahwa anak adalah generasi penerus bangsa. Jika generasi penerus bangsanya baik, akan menghasilkan sebuah negara yang baik dan adil.

\section{DAFTAR PUSTAKA}

\section{Buku}

BPMPKB Kota Padang. Laporan Pelaksanaan

Kota Padang Sebagai Kota Layak Anak Tahun 2015. Padang: Badan
Pemberdayaan Masyarakat, Perempuan dan Keluarga Berencana, 2015. Laporan Pelaksanaan Kota Padang Sebagai Kota Layak Anak Tahun 
2014. Padang: Badan Pemberdayaan Masyarakat, Perempuan dan Keluarga Berencana, 2014.

\section{Laporan Pelaksanaan Kota}

Padang Sebagai Kota Layak Anak Tahun 2013. Padang: Badan Pemberdayaan Masyarakat, Perempuan dan Keluarga Berencana, 2013.

Dinsosnaker Kota Padang. Rencana Strategis Tahun 2014-2019. Padang: Dinas Sosial dan Tenaga Kerja Kota Padang Tahun, 2014.

Dinas Sosial Dan Tenaga Kerja Kota Padang. Laporan Pelatihan Service Hand Phone Bagi Anak Jalanan Kegiatan Pelatihan Keterampilan Dan Praktek Belajar Kerja Anak Jalanan Di Rumah Perlindungan Sosial Anak. Padang:

Dinas Sosial Dan Tenaga Kerja Kota Padang, 2011. - Laporan Pelatihan Keterampilan MontirSepedaMotor BagiAnakJalanan Kegiatan Pelatihan Keterampilan Dan Praktek Belajar Kerja Anak Jalanan Di Rumah Perlindungan Sosial Anak. Padang: Dinas Sosial Dan Tenaga Kerja Kota Padang, 2012. - Laporan Pelatihan Keterampilan MontirSepedaMotor BagiAnakJalanan Kegiatan Pelatihan Keterampilan Dan Praktek Belajar Kerja Anak Jalanan Di Rumah Perlindungan Sosial Anak. Padang: Dinas Sosial Dan Tenaga Kerja Kota Padang, 2013. - Laporan Pelatihan Service Hand Phone Bagi Anak Jalanan Kegiatan Pelatihan Keterampilan Dan Praktek Belajar Kerja Anak Jalanan Di Rumah Perlindungan Sosial Anak. Padang: Dinas Sosial Dan Tenaga Kerja Kota Padang, 2014.

Marzuki, Peter Mahmud. Penelitian Hukum. Cetakan Ke-7. Jakarta: Kencana Media Group, 2011.

\section{Jurnal}

Nurwijayati, Andriyani Mustika. "Eksploitasi Anak: Perlindungan Hukum Anak Jalanan Dalam Perspektif Hukum Pidana Di Daerah Yogyakarta”. Jurnal Jurisprudence Vol. 1, No. 1, (Juli 2012): 208.

Aulina, Choirun Nisak. "Penanaman Disiplin Pada Anak Usia Dini”. Jurnal Pedagogia Vol. 2 No. 1 (Februari 2013): 36.

\section{Makalah}

S., Laurensius Arliman. Penyuluhan Hukum Perlindungan Anak disampaikan di Aula SMA Negeri 6 Kota Padang. Padang: Sekolah Tinggi Ilmu Hukum Padang, 2015.

\section{Skripsi / Thesis / Disertasi}

Endrawati, Netty. "Perlindungan Hukum Terhadap Pekerja Anak Di Sektor Informal (Studi Kasus Di Kota 
Kendiri)". Disertasi Ilmu Hukum

Program Pasca Sarjana Dotor Ilmu

Hukum.. Surabaya: UNTAG, 2011.

Tidak Dipublikasikan.

Octalina, Benedhicta Desca Prita.

"Perlindungan Hukum Terhadap

Anak Korban Eksploitasi Ekonomi”.

Jurnal Skripsi Ilmu Hukum Program

KekhususanPeradilandanPenyelesaian

Sengketa Hukum. Yogyakarta: Fakultas

Hukum Universitas Atmajaya, 2014.

Tidak Dipublikasikan.

\section{Peraturan Perundang-undangan}

Undang-undang Nomor 35 Tahun 2014 tentang

Pengganti Undang-Undang Nomor
23 Tahun 2002 Tentang Perlindungan Anak.

Peraturan Daerah Kota Padang nomor 2 Tahun 2012 tentang Pembinaan dan Perlindungan Anak.

\section{Naskah Internet}

Minangkabaunews, "Sosialisasi Perda Nomor 1 tentang Pembinaan Anak Jalanan, Gelandangan, Pengemis dan Pedagang Asongan", http://minangkabaunews. com/artikel-2874-sosialisasi-perdanomor-1-tentang-pembinaan-anakjalanan-gelandangan-pengemis-danpedagang-asonganda.html. Diakses 2 Desember 2015. 